\title{
Artroplastias Totais do Quadril com Prótese PCA (Porous Coated Anatomic)
}

\author{
Total HIP Arthroplasty with PCA (Porous Coated Anatomic) Prosthesis
}

Sérgio Nogueira Drumond ${ }^{1}$, Edson Barreto Pana², José Paulo Sabino de Almeida ${ }^{3}$, Leandro Vaz de Melo Campos ${ }^{3}$

\section{RESUMO}

Foram realizadas 27 artroplastias totais do quadril nos anos de 1988 e 1993, com próteses do quadril PCA (Anatômica com revestimento poroso) em 26 pacientes. O tempo médio de seguimento foi de nove anos. Foram excluídos desta avaliação sete quadris: um devido a infecção profunda precoce, dois referentes a pacientes falecidos de causa não relacionada a operação e quatro em que os pacientes não foram localizados para a presente avaliação. A idade média no tempo da operação foi de 53 anos. 0 diagnóstico pré-operatório foi de osteoartrite primária em nove pacientes, osteoartrite secundária em sete pacientes e artrite inflamatória em quatro pacientes. Os pacientes foram avaliados do ponto de vista clínico, radiográfico e subjetivo. As radiografias foram estudadas em relação a ocorrência de osteólise, migração ou afrouxamento da taça, desgaste do polietileno, desprendimento de contas, afundamento ou afrouxamento da haste femoral, reabsorção proximal do fêmur, reação periosteal, hipertrofia cortical e pedestal. Os resultados clínicos foram bons em 17 quadris (85\%). Três quadris apresentaram maus resultados (15\%) devido a migração e soltura da taça em dois casos e desgaste do polietileno em um caso. Houve concordância entre os resultados clínicos e subjetivos. Entretanto algumas alterações radiográficas observadas não se relacionaram com maus resultados.

Descritores: Artroplastia Total do Quadril, Prótese, Quadril

\section{SUMMARY}

Between 1988 and 1993 we performed 27 hip arthroplasties with the PCA prosthesis (Porous Coated Anatomic) in 26 patients. The average duration of the follow-up was nine years. We excluded seven hips from this review: one due early deep infection, two died of unrelated cause, and four were lost to follow-up evaluation. The average age at surgery was 53 years. The preoperative diagnosis was primary osteoarthritis in nine patients, secondary osteoarthritis in seven patients, osteonecrosis in six patients and inflammatory arthritis in four patients. The patients were analysed clinically, radiographically and subjectively. The X-Rays were studied for the occurrence of osteolysis, migration or loosening of the cup, wear of the polyethylene, beads shedding, subsidence or loosening of the stem, stress shielding, periosteal reaction and distal cortical hypertrophy. Seventeen hips (85\%) were rated clinically good results. Three hips were rated poor (15\%) due migration of the cup in two cases and wear of the polyethylene in one case. There were concordance between the clinical and the subjective results. However several radiographic findings were not related to poor results.

Key words: Arthroplasty, Hip, Prosthesis.
Trabalho realizado no Hospital Ortopédico - Associação Mineira de Reabilitação - Belo Horizonte- MG

1. Prof. Adjunto da Faculdade de Medicina da UFMG, Mestre em Cirurgia. Ortopedista, Chefe do Serviço de Cirurgia do Quadril do Hospital Ortopédico.

2. Ortopedista do Hospital Biocor

3. Residentes do Serviço de Cirurgia do Quadril do Hospital Ortopédico
Hospital Ortopédico Associação Mineira de Reabilitação Belo Horizonte - MG

1. Associate Professor, UFMG College of Medicine, Master in Surgery. Orthopedist. Head of the Hip Surgery Service, Hospital Ortopédico.

2. Orthopedist, Hospital Biocor.

3. Resident. Surgery Service, Hospital Ortopédico. 


\section{INTRODUÇÃO}

As artroplastias totais não cimentadas do quadril tornaram-se muito populares na década de oitenta. No entanto, os primeiros resultados foram desapontadores pois, apesar de haver ocorrido osteointegração, muitos pacientes permaneciam com dor e insatisfeitos com os resultados.

As próteses PCA (POROUS COATED ANATOMIC) sofreram também, nas primeiras séries, um elevado número de fracassos relacionados com dor persistente e incapacitante na coxa, claudicação, evidência radiográfica de afundamento e afrouxamento da haste femoral e migração da taça acetabular 2,7,13

Apesar dos resultados a curto prazo apresentarem problemas, havia por parte de alguns autores entusiasmo em continuar com este tipo de prótese, considerando que os maus resultados iniciais deviam-se, em parte, à curva de aprendizado e a utilização de projetos de primeira geração. ${ }^{12}$ As próteses PCA de primeira geração apresentaram altos níveis de fracassos devido ao uso da cabeça de $32 \mathrm{~mm}$ de diâmetro, com polietileno delgado o que provocava o rápido desgaste ${ }^{10,14}$ e osteólise, ${ }^{11,16,17} \mathrm{com}$ afrouxamento dos componentes. Observou-se também um número elevado de contas que se soltaram, contribuindo para o fracasso do implante. ${ }^{5}$ Outros problemas relacionam-se com a técnica cirúrgica que admitia componentes de menor tamanho, os quais originaram dor na coxa, micromovimentos da haste com afundamento e interposição de tecido fibroso e migração da taça, com perda de fixação biológica. ${ }^{10}$ Técnicas mais atuais prevêem o preenchimento completo do canal, com fixação mecânica imediata e uma horizontalização maior da taça acetabular. Além disto houve aprimoramento técnico de acordo com a curva de aprendizado e melhora dos processos industriais de fabricação das próteses com melhor fixação das contas para osteointegração. 4,6,15

Avaliações mais recentes das próteses PCA mostram a preocupação dos autores com o afrouxamento asséptico acetabular, ${ }^{1}$ com o afrouxamento asséptico femoral ${ }^{9}$ e com a presença de osteólise. A osteólise, principalmente, tem se tornado uma grande preocupação neste tipo de prótese pela grande perda óssea produzida e pelo elevado índice encontrado que foi descrito de 15\% a 39\%. ${ }^{11,16,17}$ Além da comparação da PCA com as próteses cimentadas ${ }^{13}$ trabalhos têm sido feitos em comparação a outras próteses sem cimento; em comparação com a Mallory-Head, as próteses PCA apresentaram maior índice de dor na coxa nos primeiros anos de acompanhamento. ${ }^{3}$ Em relação à prótese isoelástica BUTEL que apresentou fracasso em $43 \%$ dos casos a PCA mostrou-se mais eficiente com $11 \%$ de falhas. ${ }^{8}$

Há poucos relatos na literatura em que as próteses do tipo PCA são estudadas com um acompanhamento mais longo. ${ }^{16}$ Neste trabalho avaliamos os pacientes operados nos anos de 1989 até 1993, com próteses de última geração, já com cabeças de diâmetro de $26 \mathrm{~mm}$ e polietilenos mais espessos

\section{INTRODUCTION}

Total hip uncemented arthroplasties became very common procedures during the 80s. Notwithstanding, the first results were disappointing because, though osteointegration had occurred, many patients still felt pain and were dissatisfied with the results.

The first PCA (Porous Coated Anatomic) series of prosthesis also presented a high number of failures related to persistent and disabling pain in the thigh, claudication, radiographic evidence of subsidence and loosening of the femoral stem, and migration of the acetabular cup. $2,7,13$

In spite of the problems indicated by the short term results, some investigators were enthusiastic about this kind of prosthesis, considering that the previous bad results were, in part, a consequence of the learning curve and of the utilization of first generation projects. ${ }^{12}$ The first generation PCA prostheses presented a high number of failures because $32 \mathrm{~mm}$ diameter heads with thin polyethylene were used, provoking quick wear ${ }^{10,14}$ and osteolysis, ${ }^{11,16,17}$ with loosening of the components. A high number of beads shed contributing to the implant failure. ${ }^{5}$ Other problems were related to the surgical technique which accepted components of smaller size, originating pain in the thigh, micromovements of the stem with subsidence, and interposition of fibrous tissue and cup migration losing biological fixation. ${ }^{10}$ Current techniques provide complete filling of the canal, with immediate mechanical fixation and greater horizontalization of the acetabular cup. Besides this, technical refinement according to the learning curve and improvement of the industrial processes which manufacture the prostheses with better fixation of the beads aiming osteointegration. $4,6,15$

More recent evaluations of the PCA prosthesis show preoccupation of the authors with the acetabular aseptic loosening, ${ }^{1}$ with the femoral aseptic loosening ${ }^{9}$ and with osteolysis. Osteolysis has become a considerable concern in this kind of prosthesis because intense bone loss is produced and indices as high as $15 \%$ to $39 \%$ were found. ${ }^{11,16,17}$ In addition to the comparison of PCA with the cemented prostheses ${ }^{13}$, it has been compared to other cementless prostheses; compared to the Mallory-Head, the PCA prosthesis presented a higher index of pain in the thigh during the first follow-up years. ${ }^{3}$ In relation to the BUTEL isoelastic prosthesis which failed in $43 \%$ of the cases, PCA was more efficient with $11 \%$ failure rate. ${ }^{8}$

There are few reports in the literature about studies with the PCA prosthesis and long term follow-up. ${ }^{16}$ In this study, patients operated on from 1989 to 1993 with state-of-the-art prosthesis with $26 \mathrm{~mm}$ diameter heads and thicker polyethylene were evaluated. 


\section{CASUÍSTICA}

Foram 27 quadris em 26 pacientes submetidos a artroplastia total do quadril, com a prótese sem cimento do tipo PCA ( POROUS COATED ANATOMIC ). Os pacientes foram operados no período de 1988 a 1993. Foram 17 pacientes do sexo masculino, sendo um caso operado de ambos os quadris e nove pacientes do sexo masculino ( Tabela 1). A idade oscilou entre 28 anos a 79 anos, com idade média de 53. Os diagnósticos mais freqüentes foram artrose primária ( nove pacientes ) artrose secundária (sete pacientes ) osteonecrose ( seis pacientes ) e artrite reumatóide, doenças correlatas do tipo espondilite anquilosante e protusão acetabular (quatro pacientes).

\section{MÉTODOS}

Vinte e seis pacientes portadores de doenças incapacitantes do quadril foram submetidos a artroplastias totais usando-se a prótese PCA (POROUS COATED ANATOMIC). Um dos pacientes foi operado dos dois quadris totalizando 27 quadris. Dos 27 quadris estudados foram avaliados 20 quadris em 20 pacientes com vistas ao resultado radiográfico e subjetivo. Foram excluídos sete quadris em seis pacientes por não completarem o tempo de acompanhamento de seis a 11 anos. Um dos pacientes teve a prótese removida devido a infecção profunda; dois pacientes faleceram de causa não relacionada ao procedimento cirúrgico (estes pacientes estavam bem e satisfeitos com o resultado da operação) três pacientes estavam bem por ocasião da última revisão feita há 3 anos atrás e como não foram localizados não fizeram parte da presente avaliação. Os pacientes foram operados de 1988 até 1993 nos Hospitais Ortopédico e Semper.

A prótese PCA é constituída de uma liga de Cromo Cobalto Molibidênio, revestida de superfície microporosa na região metafisária da haste e em toda a superfície externa do componente acetabular. A camada microporosa é formada por um aglomerado de pequenas esferas de aproximadamente 300 microns, destinadas a osteointegração. A fixação inicial da prótese é pelo mecanismo de Press-fit (encaixe sob pressão) sendo que, a médio prazo, com o crescimento ósseo entre as microesferas ocorre a osteointegração ou fixação biológica. A haste apresenta área de corte transversal trapezoidal, acompanhada de angulação que

\section{CASUISTIC}

Twenty-seven hips from 26 patients submitted to uncemented PCA (porous coated anatomic) total hip arthroplasty. Seventeen male and nine female patients patients were operated on from 1988 to 1993. One male patient was operated on both hips (Table 1). Ages ranged from 28 to 79 years, average 53 years. The most frequent diagnoses were primary arthrosis (nine patients), secondary arthrosis (seven patients), osteonecrosis (six patients), and rheumatoid arthritis, related conditions of ankylosant spondilitis and acetabular protrusion (four patients).
№ de Pacientes - \# of Patients

9

17

26
METHOD
Twenty-six patients with disabling hip conditions were submitted to total arthroplasty using the PCA (porous coated anatomic) prosthesis. One of the patients was operated on both sides, totalling 27 hips. From the 27 studied hips, 20 were evaluated in 20 patients aiming radiographic and subjective results. Seven hips from six patients were excluded since the six to 11-year follow-up was not completed. One of the patients had the prosthesis removed due to a deep infection; two patients died due to causes non-related to the surgical procedure (these patients were in good condition and pleased with the result), three patients were in good condition when the last revision was made 3 years before but they were not found and did not participate of this evaluation. The patients were operated on from 1988 to 1993 in the Ortopédico and Semper Hospitals.

The PCA prosthesis is made up by a chromium, cobalt and molybdenum alloy, coated by a microporous surface in the metaphyseal region of the stem and in all external surface of the acetabular component. The microporous layer is formed by a cluster of small spheres of approximately 300 micra, aiming osteointegration. The initial fixation of the prosthesis is made by the Press-fit mechanism and, as bone grows within the microspheres osteointegration or biological fixation occurs. The stem presents a trapezoid transversal section area, accompanied by an angulation which corresponds to the antecurvature of the femur proximal portion. Thus, the prosthesis is specific for the 
corresponde a antecurvatura da porção proximal do fêmur. Daí ser a prótese específica para o lado direito e esquerdo. A taça é hemisférica e apresenta duas orelhas de fixação adicional na face lateral com objetivo de prevenir rotação. A cabeça femoral é intercambiável e tem diâmetro de $26 \mathrm{~mm}$. As próteses foram implantadas sem cimento exceto em dois quadris em que as hastes foram cimentadas ( duas próteses híbridas ). O acesso usado foi

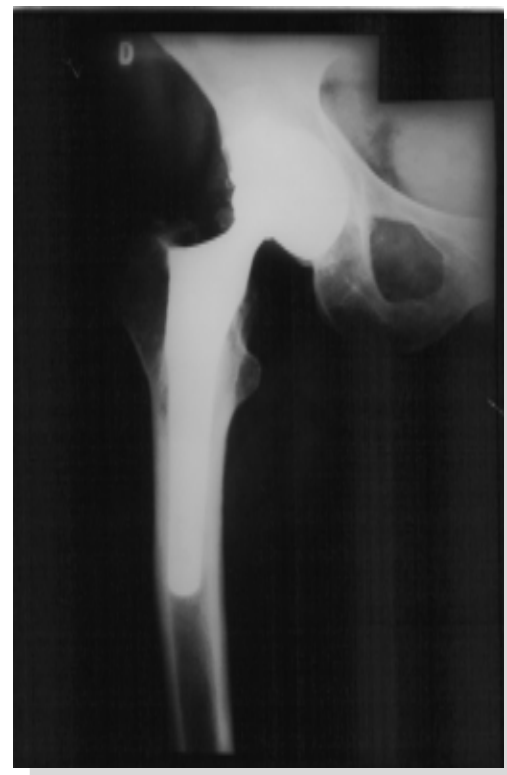

Fig. 1 - TNAP, sexo feminino, portadora de artrose primária do quadril, operada aos 57 anos, de prótese total do quadril PCA, há 11 anos. Resultados clínico e subjetivo satisfatórios. A radiografia atual mostra osteointegração da taça e de toda a haste. Há reabsorção óssea proximal e desprendimento de quatro contas da taça acetabular. Nota-se discreto varismo da haste e discreto desgaste do polietileno.

Fig. 1 - TNAP, female, primary arthrosis in the hip, operated on when 57 year-old, total hip PCA prosthesis, eleven years ago. Clinical and subjective results satisfactory. Today, the radiograph shows cup and stem osteointegration. Bone reabsorption proximal and shedding of four beads in the acetabular cup. Discreet varism of the stem and discreet wear of the polyethylene.

principalmente o ântero-lateral, descrito por Hardinge, sem secção do grande trocanter. No pós-operatório os pacientes foram mantidos com restrição parcial de apoio por tempo que variou entre 2 a 3 meses. Os pacientes foram avaliados periodicamente segundo critérios clínicos, radiográficos e subjetivos. A avaliação clínica foi feita segundo os critérios de Merle D'Aubigne-Postel, modificada por Charnley. A avaliação subjetiva considerou o grau de satisfação do paciente na última consulta. Foi avaliado right or left sides. The cup is hemispherical and presents two flaps for additional fixation in the lateral aspect aiming to prevent rotation. The femoral head is interchangeable and has a $26 \mathrm{~mm}$ diameter. The prostheses were implanted without cement with the exception of two hips where the stems were cemented (two hibrid prostheses). Access was mainly anterior-lateral according to Hardinge, and the great trochanter was not secctioned. During

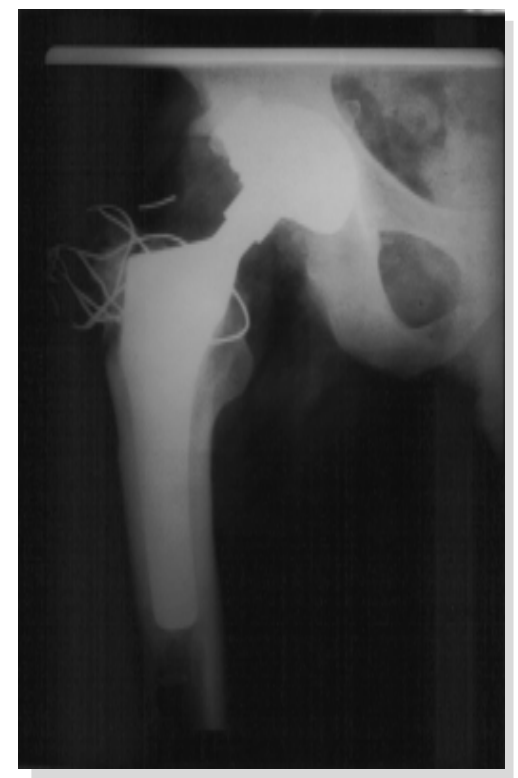

Fig. 2 - DG, sexo masculino, portador de osteonecrose do quadril, operado aos 44 anos, de prótese total do quadril PCA, há 11 anos. Resultados clínicos e subjetivo satisfatórios. A radiografia mostra taça osteointegrada sem desgaste do polietileno. Na porção femoral há hipertrofia cortical distal, pedestal e osteointegração de toda haste.

Fig. 2 - DG, male, hip osteonecrosis, operated on when 44 year-old, total hip PCA prosthesis, eleven years ago. Clinical and subjective results satisfactory. The radiograph shows osteointegrated cup with no polyethylene wear. In the femoral portion there is a distal cortical hyperthrophy, pedestal and osteointegration of the stem.

the post-operative period the patients were mantained with partial restriction during 2 to 3 months. They were periodically evaluated according to clinical, radiographic and subjective criteria. Clinical evaluation was effected according to the Merle D'Aubigne-Postel criteria, modified by Charnley. Subjective evaluation considered the the patient's satisfaction in the last visit. Evolution of pain in the thigh was clinically evaluated in the post-operative period. Radiographic evaluation was effected according to a set of 
clinicamente a evolução da dor na coxa dos pacientes no pósoperatório. A avaliação radiográfica foi feita determinando-se a presença de vários achados. Os aspectos analisados foram: Stress Shielding, afundamento da haste, presença de pedestal, desprendimento de contas, hipertrofia cortical, osteólise, demarcação, osteointegração, desgaste do polietileno, posição da haste femoral e da taça. Foram selecionados para a prótese sem cimento os pacientes que apresentavam dor incapacitante, dificuldade para a marcha e limitação grave dos movimentos e função do quadril. Todos os pacientes apresentavam boa qualidade óssea pelas radiografias. A idade também foi considerada: dos 26 pacientes apenas quatro apresentavam idade superior a 60 anos na época da operação.

O tempo médio de acompanhamento foi de nove anos, sendo o maior tempo de 11 anos e o menor de seis anos. findings: stress shielding, subsidence of the stem, shedding of the beads, cortical hyperthrophy, osteolysis, demarcation, osteointegration, wear of the polyethylene, position of the femoral stem and of the cup. Patients with disabling pain, difficulty when walking and severe limitation of movements and hip function were selected to the cementless prosthesis. All the patients presented bones of good quality when X-rayed. Age was also considered: in 26 patients only four were above 60 years when operated on.

Mean follow-up period was nine years, ranging from six to 11 years.
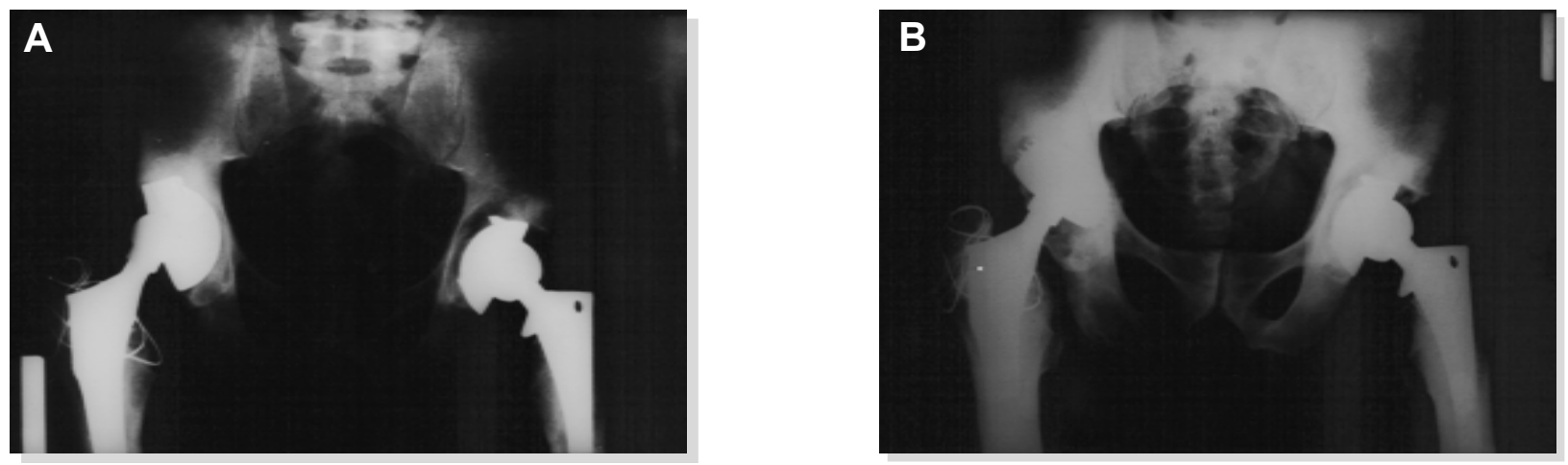

Fig. 3 A-B - JL, sexo masculino, portador de artrose primária, operado do quadril D aos 39 anos, de prótese PCA. Evoluiu com desprendimento da taça acetabular com verticalização. Notou-se presença de moderada corrosão, sem osteólise importante. A taça foi revisada após 4 anos de acompanha-mento usando-se taça de titânio rosqueada e enxerto ósseo. Considerado um mau resultado. À esquerda uma prótese AML (Anatomic Medullary Locking).

Fig. $3 \mathbf{A}-\boldsymbol{B}-J L$, male, primary arthrosis, operated on the right hip when 39 year-old, PCA prosthesis. Evolution with shedding of the acetabular cup with verticalization. Moderate corrosion was observed, non-significant osteolysis. The cup was revised after a 4-year follow-up using titanium screwed cup and bone graft. It is considered a bad result. In the left, an AML (Anatomic Medullary Locking) prosthesis.

\section{RESULTADOS}

Os resultados dos 20 quadris em 20 pacientes foram satisfatórios em 17 pacientes e insatisfatório em três pacientes. As figuras 1 e 2 mostram o aspecto radiográfico de dois casos satisfatórios. Houve concordância entre as avaliações clínica, radiográfica e subjetiva. O fracasso de três casos deveu-se a migração e afrouxamento do componente acetabular em dois casos e desgaste do polietileno em um caso. Os casos em que houve afrouxamento da taça foram submetidos a revisão com taça rosqueada de titânio e enxerto ósseo (Fig. 3 A-B); o caso com desgaste do polietileno teve o mesmo trocado, mantendo-se a taça metálica original. (Fig. 3 A-B).

\section{RESULTS}

The results for the 20 hips in 20 patients were satisfactory in 17 and non-satisfactory in three patients. Figures 1 and 2 show the radiographic aspect of two satisfactory cases. There was agreement between the clinical, radiographic and subjective evaluations. The failure of three cases was due to migration and loosening of the acetabular component in two cases and wear of the polyethylene in one case. The cases of loosening of the cup were submitted to revision with a titanium screwed cup and bone graft (Fig. 3 A-B); the patient with polyethylene wear was submitted to replacement of the polyethylene maintaining the original metalic cup (Fig. 3 A-B). 


\section{COMPLICAÇÕES}

Houve um caso de infecção profunda refratária ao tratamento clínico, sendo necessária a remoção do implante, deixando-se uma artroplastia de ressecção tipo Girdlestone. Houve dois casos com migração vertical da taça, necessitando revisões, que foram feitas com taça de titânio rosqueadas. Houve um caso de desgaste do polietileno, sem prejuízo de fixação da taça metálica, possibilitando a troca somente do polietileno. Houve um caso de luxação pósoperatório que foi submetido a redução incruenta, sem prejuízo do resultado final.

\section{COMPLICATIONS}

One patient presented deep refractory infection demanding remotion of the implant, and a ressection arthroplasty Girdlestone type was effected. Two cases had a vertical migration of the cup demanding revisions, which were made with titanium screwed cups. There was one case of polyethylene replacement due to wear harmless to the metalic cup fixation. One case of postoperative luxation was submitted to bloodless reduction and the final result was unaltered.
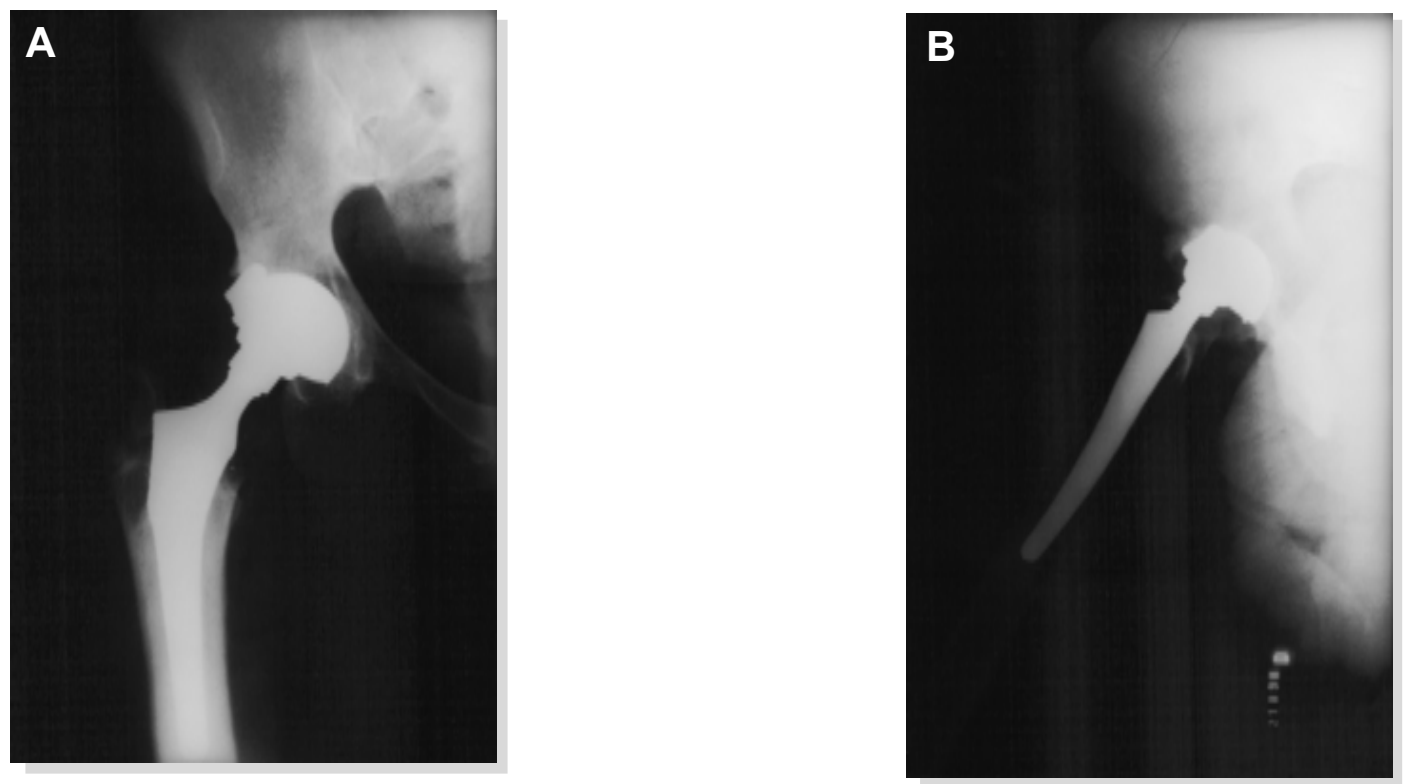

Fig. 4 A-B - AAO, sexo feminino, portadora de artrose secundária, operada aos 27 anos, de prótese PCA. Com acompanhamento de 8 anos apresentou falha da prótese com desgaste do polietileno, com muita dor e extrema incapacidade. Foi revisada cimentando-se um novo polietileno na taça metálica. Considerado um mau resultado.

Fig. 4 A-B - AAO, female, secondary arthrosis, operated on when 27 year-old, PCA prosthesis. The 8-year followup presented failure of the prosthesis with polyethylene wear, intense pain and extreme disability. Revised cementing new polyethylene in the metalic cup. Considered a bad result.

\section{ANALISE RADIOGRÁFICA}

A análise radiográfica após o período de acompanhamento de nove anos mostrou uma série de achados radiográficos. Os achados mais freqüentes foram pedestal, osteointegração total da haste, soltura de contas, hipertrofia cortical e desgaste do polietileno (Tabela 3). Foram achados com menor freqüência a demarcação femoral, migração da taça, stress shielding (reabsorção proximal), afundamento da haste e colocação da haste em varo. Não foram encontrados casos de osteólise ou calcificação periarticular. (Tabela 4) (Figs. 1 e 2). Os achados que representaram

\section{RADIOGRAPHIC ANALYSIS}

The radiographic analysis after the nine-year follow-up period revealed a series of findings. The most frequent findings were pedestal, total osteointegration of the stem, shedding of the beads, cortical hyperthrophy and wear of the polyethylene (Table 3). Less frequent findings were femoral demarcation, migration of the cup, shielding stress, subsidence and varism of the stem. No osteolysis or periarticular cases were found (Table 4) (Figs. 1 and 2). The findings with clinical repercussion adversely affecting the final results were migration of the cup in two cases and severe 
repercussão clínica, afetando adversamente os resultados finais, foram a migração da taça em dois casos e desgaste grave do polietileno que exigiram cirurgia de revisão. Os outros achados radiológicos não apresentaram maior repercussão clínica. wear of the polyethylene demanding surgical revision. The other radiological findings did not present clinical repercussion.

\section{ACHADOS RADIOGRÁFICOS MAIS FREQUENTES (20 CASOS) MOST FREQUENT RADIOGRAPHIC FINDINGS (20 CASES)}

TABELA 3 - TABLE 3

\begin{tabular}{lc}
\hline \hline Achados radiográficos & No de Casos \\
\hline Pedestal & 12 \\
Osteointegração total & 10 \\
Soltura de contas & 8 \\
Hipertrofia cortical & 6 \\
Desgaste do polietileno & 5 \\
\hline \hline
\end{tabular}

TABELA 4 - TABLE 4

ACHADOS RADIOGRÁFICOS MENOS FREQUENTES (20 CASOS) LESS FREQUENT RADIOGRAPHIC FINDINGS (20 CASES)

\begin{tabular}{lc}
\hline \hline Achados radiográficos & No de Casos \\
\hline Demarcação fenural & 4 \\
Migração da taça & 2 \\
Stress shielding & 2 \\
Afundamento da haste & 1 \\
Varismo da haste & 1 \\
Osteólise & 0 \\
Calcificação periarticular & 0 \\
\hline \hline
\end{tabular}

\section{DISCUSSÃO}

As próteses do quadril tipo PCA apresentaram resultados discrepantes nas diferentes avaliações na literatura. Muitos dos relatos de maus resultados deveram-se ao desenho original da prótese, com polietileno delgado, cabeça de $32 \mathrm{~mm}$, problemas na produção da prótese com soltura de contas e a curva de aprendizado. 2,7,10,11,12,13,14,16,17 As próteses de geração mais atualizada, usadas pelo autor apresentaram melhores resultados, sem evidência de dor na coxa e sobrevida mais longa dos implantes. $4,6,15,16$

As próteses do quadril sem cimento PCA apresentaram um resultado satisfatório em $85 \%$ dos casos. Os $15 \%$ restantes apresentaram falha do componente acetabular sendo $10 \%$ por migração e afrouxamento e $5 \%$ por desgaste do polietileno. A dor na coxa foi observada em dois pacientes mas não interferiram no resultado final desaparecendo com o tempo em um caso e tornando desprezível em outro.

Não foram observados casos de osteólise, migração ou afrouxamento da haste. Estes resultados coincidem com os melhores resultados da literatura.

\section{DISCUSSION}

Hip PCA prosthesis shows discrepant results as far as literature is concerned. Many of the reported bad results were attributed to the original design of the prosthesis, with thin poliethylene layer, $32 \mathrm{~mm}$ head, problems of production with shedding of the beads and the learning curve. $2,7,10,11,12,13,14,16,17$ The last prosthesis used by the author produced better results: no evidence of pain in the thigh and longer survival of the implants. 4,5,15,16

The hip cementless PCA prosthesis presented satisfactory results in $85 \%$ of the cases. The other $15 \%$ presented failure of the acetabular component, $10 \%$ due to migration and loosening and $5 \%$ due to polyethylene wear. Pain in the thigh was observed in two patients by did not interfere in the final results, fading in one case and becoming negligible in another.

No osteolysis, migration or stem loosening were observed. These results agree with the best results found in the literature. 


\section{REFERÊNCIAS}

1. Astion, D.J., Salvan, P., Stulberg, B.N. et al.: The Porous - Coated Anatomic total hip prosthesis: failure of the metal-backed acetabular component. J. Bone Joint Surg (Am) 78: 755-766, 1996.

2. Barrack, R.L., Jasty, M. Bragdon, C., et al: Thigh Pain Despite Bone Ingrowth Into Uncemented Femoral Stems. J. Bone Joint Surg. (Br) 74: 507-510, 1992.

3. Burkart, B.C., Bourne, R.B.,, Rorabeck, C.H. et al: Thigh Pain in Cementless Total Hip Arthroplasty. Orthop. Clin. North Am. 24: 645653, 1993.

4. Callaghan, J.J., Heekin, R.D., Saudry, C.G., et al: Evaluation of the learning curve associated with uncemented primary Porous-Coated Anatomic total hip arthroplasty. Clin Orthop. 282: 132-144, 1992.

5. Campbell, A.C.L., Rorabeck, C.H. Bourne, R.B., et al: Thigh Pain After Cementless Hip Arthroplasty. J. Bone Joint Surg (Br) 74: 63-66, 1992.

6. Demuynck, M., Haentjens, P., Valkeneer, O. et al.: Total hip arthroplasty with the porous-coated anatomic (PCA) prosthesis: the acetabular component. Acta Orthop. Belg. 59 - Suppl. I, 1993.

7. Haddad, Jr.R.J., Skalley, T.C., Cook, S.D. et al.: Clinical and Roentgenographic Evaluation of Noncemented Porous-Coated Anatomic Medullary Locking (AML) and Porous-Coated Anatomic (PCA) Total Hip Arthroplasties. Clin Orthop 258: 176-182, 1990.

8. Jacobsson, S. Djerf, K., Gillquist, J., et al: A Prospective Comparison of Butel an P.C.A. Hip Replacement. J. Bone Joint Surg. (Br) 75: 624629, 1993.

9. Kim, Y., Kim, V.E.M.: Early Migration of Uncemented Porous Coated Anatomic Femoral Component Related to Aseptic Loosening. Clin.Orthop. 295: 146-155, 1993.

10. Kim, Y., Kim, V.E.M.: Uncemented Porous-Coated Anatomic Total Hip Replacement. J. Bone Joint Surg (Br) 75: 6-14, 1993.

11. Learmonth, I.D., Hussel, J.G., Grobler G.P.: Unpredictable progression of osteolysis following cementless hip arthroplasty. Acta Orthop Scand 67: 245-248, 1996.

12. Lins, R.E., Barnes, B.C., Callaghan, J.J. et al.: Evaluation of Uncemented Total Hip Arthroplasty in Patients With Avascular Necrosis of the Femoral Head. Clin Orthop 297: 168-173, 1993.

13. Maric, Z., Karpman, R.R.: Early Failure of Noncemented Porous Coated Anatomic Total Hip Arthroplasty. Clin. Orthop 278: 116-120, 1992.

14. Ries, M.D., Collins, D.K., Lynch, F.: Separation of the Polyethylene Liner from Acetabular Cup Metal Backing. Clin. Orthop. 282: 164169, 1992.

15. Wellen, P.V., Demuynck, M., Haentjens, P. et al.: Total hip arthroplasty with the porous-coated anatomic (PCA) prosthesis: the femoral component. Acta Orthop. Belg. 59 - Suppl. I, 1993.

16. Xenos, J.S., Callaghan, J.J., Heekin, R.D., et al : The Porous-Coated Anatomic total hip prosthesis, inserted without cement. J. Bone Joint Surg. (Am) 81: 74-82, 1999.

17. Xenos, J.S., Hopkinson, W.J., Callaghan, J.J., et al: Osteolysis Around an Uncemented Cobalt Chrome Total Hip Arthroplasty. Clin. Orthop. 317: 29-36, 1995 